\title{
KEBERLANJUTAN DAN PERUBAHAN" ORIENTASI PERMUKIMAN KAJIAN FENOMENA PERMUKIMAN AIRMATA DI BANTARAN KALI KACA KOTA KUPANG
}

\author{
Reginaldo Christophori Lake', Robertus M. Rayawulan², Donatus Arakian ${ }^{3}$ \\ Program Studi Arsitektur, Fakultas Teknik, Universitas Katolik Widya Mandira \\ E-mail: egilake@yahoo.com
}

\begin{abstract}
ABSTRAK
Permukiman Airmata adalah permukiman yang berada di bantaran sungai Kali Kaca dirancang dan dibangun para pendiri permukiman berdasarkan keadaan lokasi, perkembangan kehidupan masyarakat setempat, kearifan lokal dan sejarah penyebaran agama Islam di kota Kupang. Permukiman Airmata tumbuh pesat sejak dijadikan kampung ziarah rohani bagi agama Islam di NTT. Karakter permukiman Airmata sangat khas sehingga menarik untuk dikaji mengenai keberlanjutan budaya bermukim di bantaran sungai Kali Kaca dan perubahannya yang diakibatkan oleh meningkatnya jumlah penduduk dan pertumbuhan kota. Permasalah penelitian dalam tulisan ini adalah bagaimana kelestarian dan perubahan (continue and change) permukiman Airmata di bantaran sungai Kali Kaca dan bagaimana seharusnya konsep keberlangsungan budaya bermukim di bantaran sungai dapat dilestarikan. Observasi lapangan dan kajian pustaka digunakan dalam penelitian ini. Hasil penelitian, terdapat indikasi perubahan fisik, fungsi dan makna dari permukiman Airmata, namun keterkaitan permukiman Airmata dengan sungai Kali Kaca cenderung dipertahankan. Keaslian dan keunikan permukiman Airmata bertahan apabila ditata dengan baik dengan konsekuensi pembenahan kegiatan ekonomi di sungai, penataan ruang permukiman dan sanitasi serta pelestarian ekosistem, sehingga kekhasan permukiman bantaran sungai, yaitu interaksi manusia dengan sungai dapat dilestarikan secara arif, dan kreatif.

Kata Kunci: perubahan orientasi, permukiman airmata, bantaran kali kaca
\end{abstract}

\section{PENDAHULUAN}

\subsection{Keberlanjutan dan Perubahan Orientasi Permukiman Airmata di Bantaran Sungai Kali Kaca}

Permukiman Airmata berada di Kelurahan Airmata, bagian wilayah kota II, kota Kupang. Munculnya keruangan permukiman Airmata secara keseluruhan mengacu pada tatanan fisik sejarah sungai Kali Kaca dan peradaban kota tua, kota Kupang. Perkembangan dan penyebaran agama Islam di kota Kupang merupakan salah satu fenomena pembentukan ruang permukiman Airmata. Keberadaan permukiman Airmata ditandai dengan berdirinya Masjid Al-Baitul Qadim. Usia Masjid Al-Baitul (Masjid pertama dan teruta di kota Kupang) adalah 212 tahun, dibangun oleh Kyai Syah'ban bin Sanga Kala pada tahun 1806 bersama umat Kristiani yang ada di sekitar permukiman Airmata kota Kupang. Permukiman Airmata sebelumnya tumbuh secara spontan akibat penggusuran pengikut Kyai Syah'ban bin Sanga Kala oleh orang Belanda dari daerah Oeba (https://id.wikipedia.org/wiki/Masjid_Agung_Al-Baitul_Qadim).

Kehidupan sosial budaya permukiman Airmata merupakan salah satu dari 3 kawasan permukiman muslim di kota Kupang, provinsi Nusa Tenggara Timur, dulu merupakan pusat Pemerintahan Kesultanan Solor, sebagian besar terdiri atas suku Sabu, Solor dan suku Arab. Nama Airmata memiliki dua makna; (1) kawasan tersebut merupakan sumber mata air sungai yang membelah kota Kupang; (2) di kawasan tersebut banyak airmata yang tumpah akibat masa penjajahan, sejarah wafat dan dimakamkannya 3 ulama yang ditangkap dan diasingkan Belanda di kawasan permukiman Airmata yakni Kyai Arsyad asal Banten, Dipati Amir Bahrain asal Bangka dan Sultan Dompu asal Bima. Makam ketiga ulama tersebut berada dalam kompleks kuburan Batu Kadera. Masyarakat permukiman Airmata pada umumnya penganut agama Islam yang taat dan hidup dalam suasana agamis, Masjid dan agama memegang peranan penting dalam kehidupan masyarakat, dan pendidikan agama sangat ditekankan pada generasi muda.

Permukiman Airmata berpola linear mengikuti pesisir bantaran sungai kali kaca. Terbentuknya pola linear merupakan pemecahan praktis dari pola penyebaran permukiman yang memiliki kecenderungan berjajar pararel sepanjang tepi sungai. Pembentukan awal permukiman Airmata orientasi rumah-rumah menghadap sungai kali kaca sejak zaman Kesulatan mengikuti aturan penataan kampung kota yang dibentuk oleh Belanda. Zaman itu pembentukan keruangan permukiman Airmata dipengaruhi oleh 2 sistem kekuasaan, yakni Kepemerintahan Raja dan Kepemerintahan Imam (keagamaan). Pembagian daerah kepemerintahan tersebut berdasarkan batas wilayah yang ada di permukiman Airmata antara lain: dari RT I-III disebut kampung pagar Sabu, yang mengatur kepemerintahan raja. Perkembangan ini ditandai dengan kedatangan bangsa Arab ke permukiman Airmata untuk berdagang dan menyebarkan agama Islam di kota Kupang. Sedangkan wilaya RT IV-VIII disebut kampung 
Imam yang mengatur keagamaan. Permukiman Airmata pada awal mula dimulai dari muara kali Dendeng dan berkembang sepanjang bantaran sungai Kali Kaca

Kehidupan penduduk di sekitar sungai Kali Kaca dapat dikatakan sudah cukup maju. Mereka tidak lagi sebagai masyarakat terbelakang yang tidak mengenal kemajuan tetapi sudah merupakan masyarakat majemuk yang mau menerima pengaruh dari luar. Seiring dengan pertumbuhan kota dan meningkatnya jumlah penduduk, permukiman Airmata berkembang tidak terkendali disepanjang sungai yang menggeser budaya bermukim di Airmata dan mengakibatkan perubahan orientasi bermukim dari masyarakat bantaran sungai Kali Kaca.

Menyadari potensi kawasan permukiman Airmata memberi andil yang besar dalam sejarah perkembangan kota Kupang. Sudah selayaknya dimasukkan kedalam kawasan cagar budaya, seperti bunyi Undang-undang Nomor 5 tahun 1992 tentang Benda Cagar Budaya pasal 1 ayat 1 dimana disebutkan bahwa benda yang dilindungi berupa cagar budaya adalah benda buatan manusia atau benda alam, bergerak atau tidak bergerak yang berupa kesatuan atau kelompok, atau bagian-bagiannya atau sisa-sisanya, yang berumur sekurangkurangnya 50 (limapuluh) tahun, atau mewakili masa gaya yang khas yang dianggap mempunyai nilai penting bagi sejarah, ilmu pengetahuan, dan kebudayaan. Sehingga kawasan ini perlu dipertahankan dan ditata kembali untuk menampilkan kekhasannya sehingga dapat dijadikan sebagai potensi daerah (Indonesia, 1992).

Fenomena permukiman Airmata menarik dicermati, terutama adanya tanda-tanda perubahan dari konsep "permukiman asli" ke konsep "permukiman baru" yang mengadopsi unsur-unsur budaya baru. Permukiman "asli" Airmata ditandai dengan ciri: fungsi sungai kali kaca sebagai bagian dari permukiman (arsitektur) sehingga pola bermukim masyarakat Airmata mengikuti pola bantaran sungai Kali Kaca (sungai Kali Kaca dijadikan pusat orientasi) dan ada pembagian zona masing-masing suku berdasarkan konsep Kepemerintahan.

Tujuan tulisan ini adalah mengupas fenomena kontinyuitas dan perubahan (continuity and change) pada permukiman Airmata di bantaran sungai Kali Kaca sebagai inspirasi internal permukiman Airmata maupun permukiman lain apabila berusaha mempertahankan konsep penataan permukiman yang khas dan jatidiri permukiman melalui pelestarian konsep budaya bermukim sesuai dengan konteks lokasi. Inspirasi dari permukiman Airmata diharapkan memberi gambaran dan arah pelestarian permukiman bersejarah di kota Kupang provinsi Nusa Tenggara Timur maupun provinsi-provinsi lain di Indonesia.

Rumusan permasalahan penelitian adalah: Bagaimana "keberlanjutan dan perubahan" yang terjadi pada permukiman Airmata di bantaran sungai kali kaca?; Bagaimana tindakan atau konsep yang perlu dilakukan untuk mempertahankan keunikan permukiman bersejarah Airmata di bantaran sungai Kali Kaca kota Kupang?. Dari tujuan dan permasalahan tersebut maka sasarannya adalah (1) mengidentifikasi faktor-faktor yang menyebabkan keterkaitan penghuni permukiman pinggir bantaran sungai dengan sungai/air; (2) mengidentifikasi penyebab pola perubahan kehidupan bantaran sungai akibat berubahnya orientasi bermukim; (3) menyusun kriteria penataan permukiman pinggir bantaran sungai di kota Kupang; (4) merumuskan konsep penataan permukiman pinggir sungai.

Metodologi yang digunakan adalah kajian pustaka didukung catatan lapangan (logbook) yang dihasilkan dari proses penelitian berbasis penelusuran tanda-tanda fisik (physical trace) (Zeisel, 1987), dan dilengkapi dengan data wawancara verbal secara etnografis (Spradley, 1997) terhimpun dalam logbook tahun 2011. Catatan lapangan sebagai data tulisan ini diambil dari tahun 2011 dengan teknik penyebaran kuisioner dan wawancara yang digunakan dalam seminar kajian permukiman kota Kupang berjudul "Karakteristik dan Faktor Keterkaitan Kondisi Permukiman Airmata Sekitar Aliran Kali Kaca” (Lake, 2011). Data fenomena keberlanjutan dan perubahan dalam catatan lapangan belum pernah digunakan sebagai bahan tulisan ilmiah dan karena isinya beragam serta detil, maka layak diangkat dan digunakan dalam tulisan ilmiah dengan tema khusus fenomena keberlanjutan dan perubahan orientasi permukiman bantaran sungai Kali Kaca.

\subsection{Tinjauan Pustaka}

Sungai telah memegang peranan yang sangat penting dalam sejarah perkembangan peradaban dan kebudayaan manusia. Sejak ribuan tahun yang lalu telah dikenal adanya suatu perkembangan peradaban manusia pada lembah sungai yang melahirkan kota-kota penting di dunia. Peranan sungai di dalam kehidupan sehari-hari, dengan adanya air, manusia memanfaatkan untuk minum, mandi, mencuci, dan kebutuhan bangunan. Dan kemudian peran sungai berkembang menjadi sarana transportasi, yang mendorong pertumbuhan permukiman seiring dengan laju pertumbuhan penduduk dan aktifitas sosial-ekonominya, makin lama perannya makin berkembang dan tidak terpisahkan lagi dari keseluruah sistem pelayanan kota (Chair, 2002).

Permukiman adalah suatu lingkungan yang terdiri dari perumahan tempat tinggal manusia dilengkapi dengan prasarana sosial, ekonomi dan kebudayaan serta pelayanan yang merupakan sub sistem kota secara keseluruhan. Permukiman juga berarti suatu sistem ekologi/ekosistem yang menghasilkan fungsi-fungsi ekonomi mata pencaharian, fungsi reproduksi, rekreasi, hubungan sesamanya, hubungan dengan Tuhan dan hubungan pelayanan seperti sarana pendidikan. sistem ini sudah mencakup tempat tinggal atau permukiman. 
Berdasarkan pada bahasan Human Settlement and Their Elements (Doxiadis, 1968) dapat didefinisikan bahwa permukiman terdiri dari: (1) Isi, berupa manusia secara individual maupun manusia selaku anggota masyarakat; (2) wadah, berupa fisik lingkungan permukiman yang terdiri dari lingkungan alam alamiah maupun lingkungan binaan manusia.

Suatu permukiman terbentuk bilamana kedua aspek di atas dapat terpadu atau saling terjadi keterkaitan. kedua elemen yaitu isi dan wadah, dapat dijabarkan lagi menjadi beberapa bagian: (1) Nature (unsur alam), mencakup sumber-sumber daya alam seperti geologi, topografi, hidrologi, tanah, iklim, dan unsur hayati seperti vegetasi dan fauna; (2) Man (manusia), mencakup segala kebutuhan pribadinya, seperti kebutuhan biologis, emosional, nilai-nilai moral, perasaan dan persepsinya; (3) Society (masyarakat), manusia sebagai bagian dari masyarakatnya; (4) Shell (lindungan), tempat dimana manusia sebagai individu dan kelompok melakukan kegiatan dan kehidupannya; (5) Network (jejaring), merupakan system alami atau yang dibuat manusia untuk menunjang berfungsinya lingkungan permukimannya, seperti jalan, jaringan air bersih, listrik, telepon, system persampahan dan lain sebagainya (Doxiadis, 1968).

Jadi perubahan permukiman dipengaruhi oleh kekuatan sosial budaya, termasuk agama, pola hubungan kekeluargaan, organisasi/kelompok sosial, cara hidup, dan adaptasi sehari-hari serta hubungan sosial antar individu. Pola permukiman bantaran sungai umumnya adalah pola linear, karena berderet-deret sepanjang pinggiran sungai mengikuti bentuk sungainya (Goenmiandari, 2010).

\subsection{Metodologi Penelitian}

Kajian pustaka dilakukan pada pustaka substansi dan pustaka metodologi. Pustaka substansi terutama pustaka yang memuat informasi tentang permukiman Airmata, antara lain laporan penelitian awal (Lake, 2011), dan logbook penelitian lapangan (Lake, 2011). Dalam kajian pustaka dilakukan proses pembacaan ulang data terfokus fenomena isi dan wadah (Goenmiandari, 2010) permukiman Airmata dengan cara mengangkat sampel (eksemplar) alam (baik berupa alam alamiah maupun binaan manusia), manusia (berupa penghuni), masyarakat (hubungan sosial, budaya, ekonomi, dan adat), tempat bernaung (rumah dan bangunan fasilitas pendukung), dan jaringan (sarana dan prasarana) permukiman (Doxiadis, 1968). Pembacaan per-kasus isi dan wadah permukiman Airmata terpilih secara purposif didasari prinsip penelusuran tanda-tanda fisik dan dipetakan hasilnya dengan teknik tabulasi yang memuat kasus, evidensi kontinyuitas (keberlangsungan) dan evidensi perubahan (change) (Purbadi, 2017). Teknik pengambilan sampel didukung oleh proporsi populasi yang ada di permukiman Airmata (1.472 jiwa) menggunakan formula jumlah populasi, variable 1 normal, besar tolesansi penyimpangan dan proporsi populasi (Surtiani, 2006) maka didapat 90 sampel. Dari hasil tabulasi-kualitatif dan kuantitatif, dilakukan proses penyimpulan yang menunjukkan adanya akumulasi indikasi keberlanjutan dan perubahan.

\section{PEMBAHASAN}

Dalam pembahasan dipaparkan temuan-temuan penelitian (hasil tabulasi) dari fenomena permukiman Airmata. pada pembahasan data permukiman Airmata dikaitkan dengan teori Human Settlement and Their Elements yakni isi dan wadah, secara khusus terfokus pada lima faktor utama tertib pembangunan permukiman (Chair, 2002) yaitu alam, manusia, masyarakat, wadah/sarana kegiatan, dan jaringan prasarana. tujuan pembahasan adalah menemukan faktor dominan "keberlanjutan dan perubahan" yang terjadi di permukiman Airmata. Diskusi dengan fenomena lain bertujuan melihat kekhasan fenomena permukiman dalam semesta yang lebih luas agar diperolah bobot pemahaman yang semakin tinggi.

Pemetaan eksemplar lima faktor utama tertib pembangunan permukiman digunakan untuk menunjukkan evidensi perubahan sekaligus evidensi kontinyitas sebab keduanya terkait secatat erat dan sulit dipisahkan karena keduanya ada secara bersama-sama dalam setiap contoh yang dipilih.

Secara formal permukiman Airmata dianggap berdiri 212 tahun yang lalu tepatnya pada tahun 1806 ketika komunitas Kyai Arsyad digusur oleh Belanda dari Oeba, kawasan pantai di belahan Utara kota Kupang,ke Fontein arah Selatan kota Kupang, hingga ke bantaran sungai kali kaca. Masjid Agung yang didirikan di permukiman Airmata dibangun di atas tanah wakaf Syah'ban bin Sanga Kala dan diberi nama Baitul Al-Qadim (rumah pertama) menjadi sejarah awal permukiman Airmata. Masjid Baitul Al-Qadim dibangun dengan perpaduan arsitektur antara unsur budaya Flores Timur dan Arab sebagai simbol perlawan warga Airmata terhadap koloni Belanda dan Jepang pada masa itu.

Sungai Kali Kaca merupakan salah satu anak sungai yang bermuara di pantai Lai-lai Besi Koepan (LLBK) dianatanya kali Liliba, kali Merdeka dan kali Kaca (kali Dendeng). Dijuluki kali Kaca karena dahulu kali tersebut jernih, dengan kejernihan tersebut masyarakat sekitar memanfaatkan sebagai sumber air minum. Penegaran terhadap kejernihan kali tersebut dipertegas oleh Pemerintah Belanda dengan memberi peraturan untuk tidak boleh membuang sampah pada kali Kaca dengan sanksi yang jelas adalah membayar denda bagi siapa saja yang telah membuang sampah pada kali Kaca. Pantai Lai-lai Besi Koepan adalah dermaga lama kota 
Kupang sebagai rantai perdagangan rempah-rempah dan cendana oleh Portugis, Cina, Jepang dan Belanda. Dalam hal perdagangan, transportasi laut selalu menyusuri sungai kali Kaca dari dermaga kota lama Kupang.

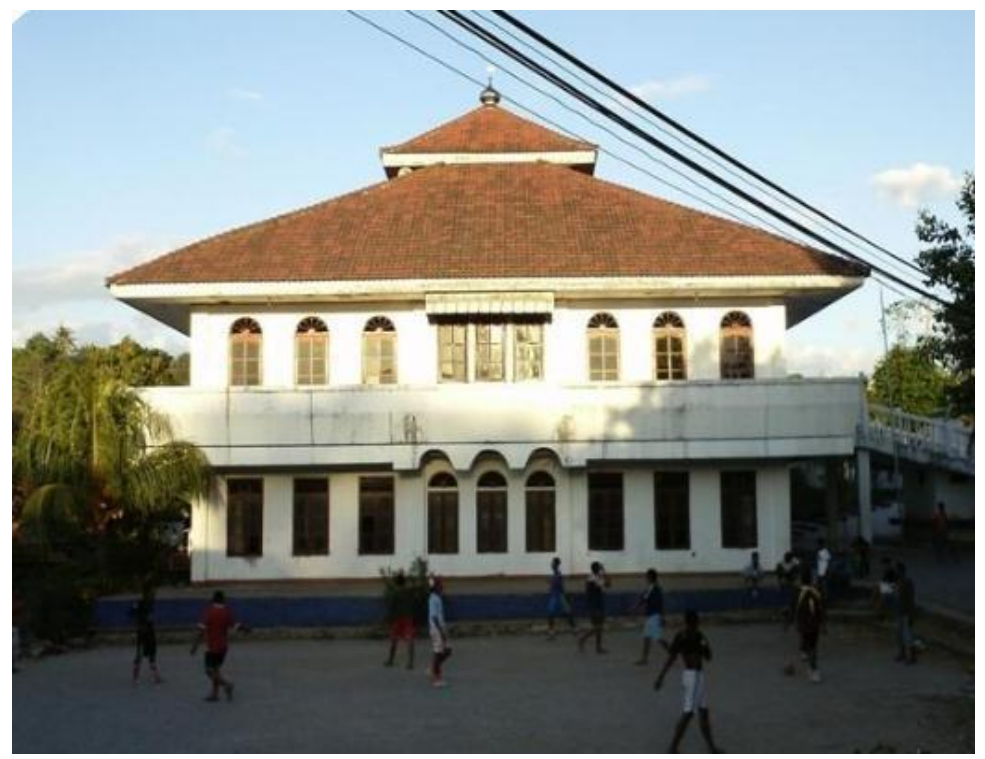

Gambar 1. Masjid Baitul Al-Qadim

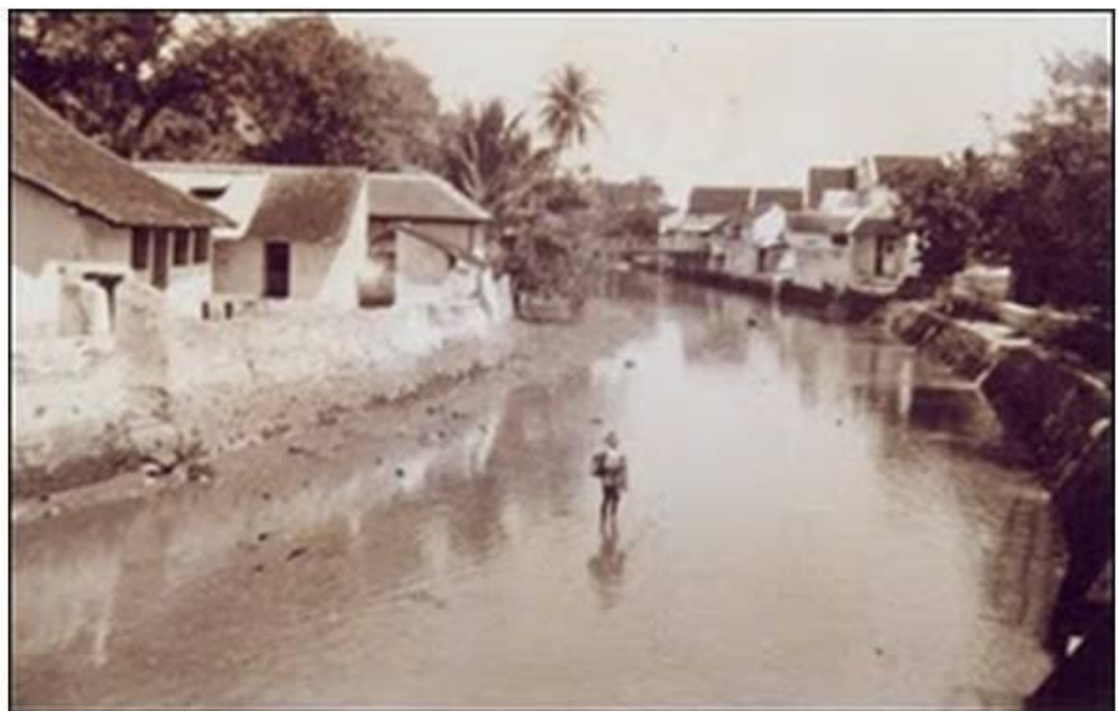

Gambar 2. Sungai Kali Kaca tempo dulu

Dari kondisi geografis dan sejarah berdirinya permukiman Airmata, terlihat bahwa sungai Kali Kaca merupakan pusat pertumbuhan, jalur pergerakan dan prasarana transportasi utama pada waktu itu. Kegiatan dan kehidupan masyarakat berorientasi ke sungai sehingga sungai mempunyai peranan dan arti yang sangat penting bagi masyarakat Airmata.

Jalan darat diperkenalkan pertama kali oleh Pemerintah sejak Belanda angkat kaki dari Nusantara. Pembuatan jalan darat tersebut dilanjutkan dengan perkembangan permukiman penduduk ke pinggir jalan dengan tujuan aksesibilitas. Pada saat ini dimana transportasi darat lebih berkembang maka masyarakat permukiman Airmata lebih memilih model transportasi darat dibandingkan dengan transportasi air. Disamping itu debit air sungai Kali Kaca menurun akibat faktor alam. 

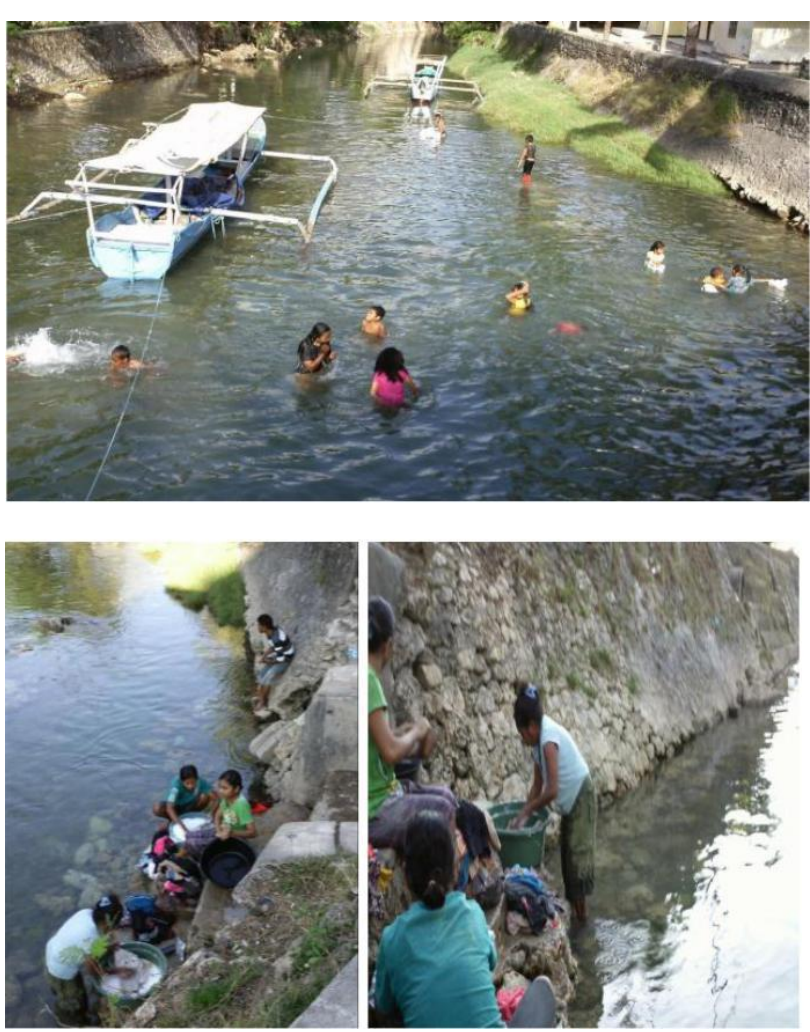
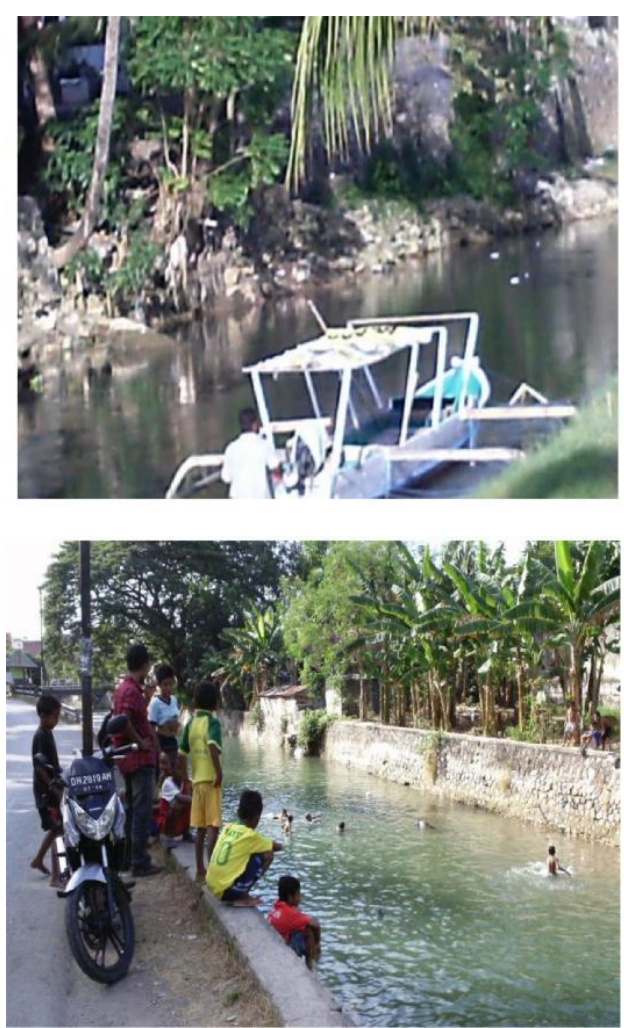

Gambar 3. Peran sungai Kali Kaca
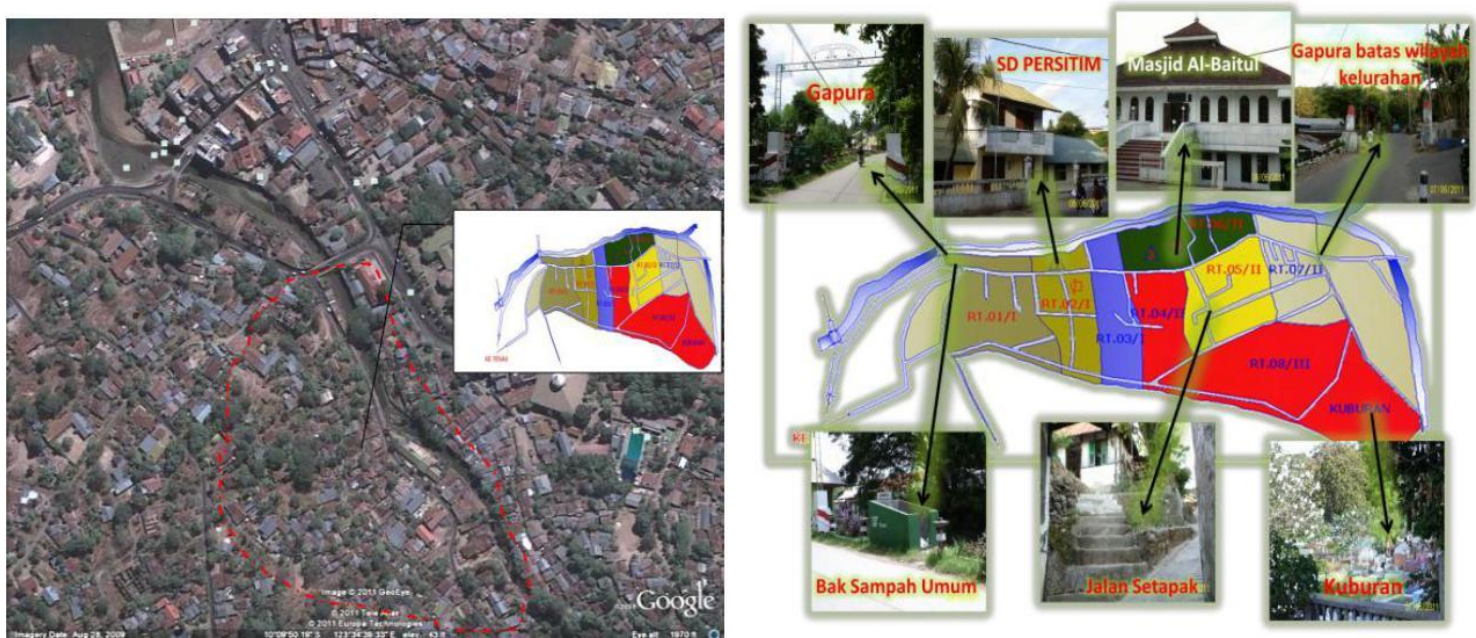

Gambar 4. Peta permukiman Airmata

Kawasan permukiman bantaran sungai Kali Kaca adalah permukiman tua yang merupakan bagian dari sejarah awal perkembangan kota Kupang. Wilayahnya merupakan bagian dari wilayah kota tua kota Kupang kelurahan Airmata. Kondisi geografis wilayah kelurahan Airmata terletak pada ketinggian 3 meter di atas permukaan laut dengan suhu rata-rata $32^{\circ} \mathrm{C}$, luas wilayah $12 \mathrm{Ha}$ yang terletak dekat dengan jembatan Selam. Letak kelurahan Airmata di pingginr sepanjang sungai Kali Kaca terbagi atas 3 (tiga) Rukun Warga dan 8 (delapan) Rukun Tetangga dengan jumlah penduduk sebanyak 1.472 jiwa (Airmata, 2017). Menurut kondisi existing serta RTRW 2017 kota Kupang, kawasan ini dipergunakan sebagai kawasan perumahan dan permukiman. Terdapat permukiman lama disepanjang tepi sungai Kali Kaca yang tumbuh secara tradisional akibat sejarah penyebaran agama Islam di kota Kupang dan akibat dari poros transportasi sepanjang tepi sungai dan tumbuh perumahan-perumahan baru baik yang terencana maupun swadaya di bagian daratan akibat dari pembangunan jalan. Perkembangan permukiman dipengaruhi oleh beberapa hal, antara lain pertambahan 
penduduk perubahan pola permukiman, pergerakan ekonomi kawasan, jalur transportasi dan lain sebagainya (Goenmiandari, 2010).

Pola permukiman terbentuk karena budaya yang menyangkut cara hidup, cara beradaptasi dengan alam dan lingkungan serta tuntutan pemenuhan kebutuhan. Pada awalnya permukiman Airmata berbentuk linear dengan arah orientasi ke sungai Kali Kaca. Bangunan merupakan bangunan tradisional bergaya Hindia Belanda, kebanyakan berbentuk limasan, perisai dan pelana.
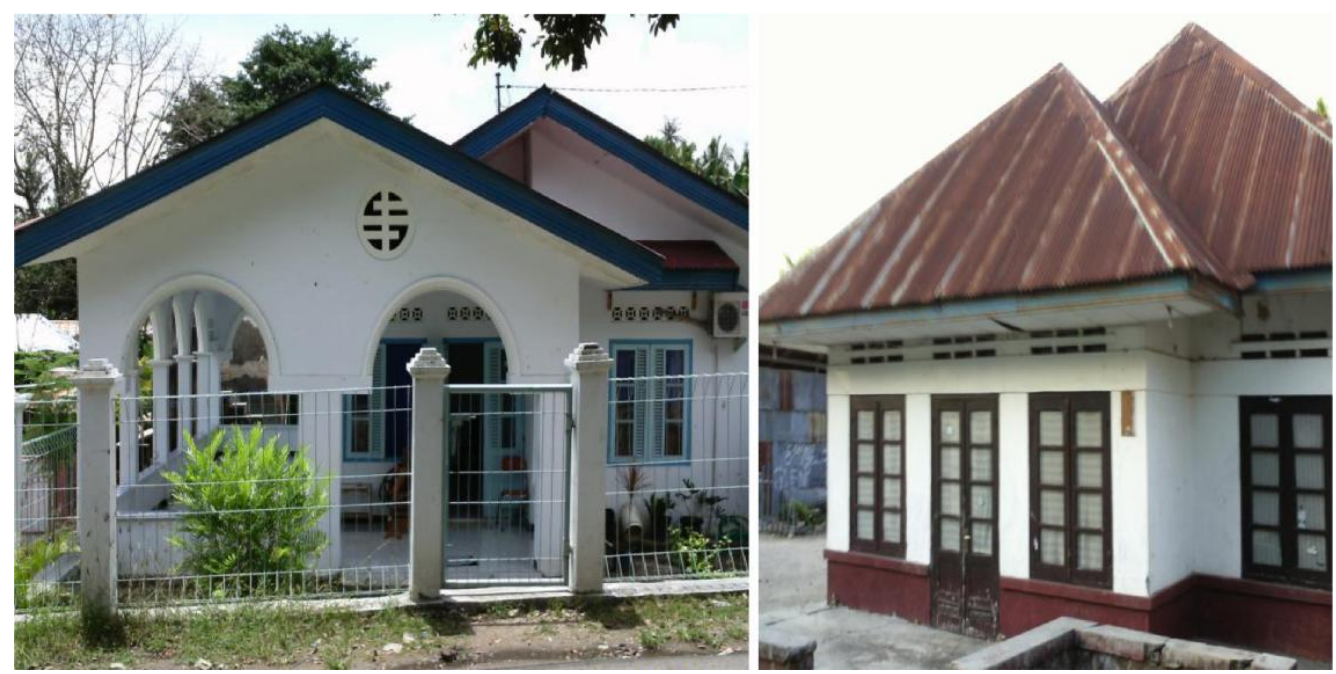

Gambar 5. Tipologi banguan rumah tinggal di permukiman Airmata

Pembahasan mengenai data-data yang diperoleh dari wawancara dan observasi langsung setelah dianalisis secara deskriptif kualitatif dan kuantitatif menghasilkan faktor-faktor yang menyebabkan keterkaitan penghuni permukiman bantaran sungai dengan sungai/air adalah (1) aktivitas transportasi sungai, hal ini dipengaruhi oleh pemenuhan sarana dan prasarananya, (2) aktivitas ekonomi sungai dan termasuk di dalamnya sebagai sumber ekonomi, (3) aktivitas mandi, cuci kakus, dan persampahan, (4) aktivitas sosial dan budaya, (5) kebutuhan akan pemenuhan air bersih dan air minum. Namun pada saat ini faktor pengikat yang masih ada adalah pada pemenuhan kebutuhan sanitasi dan penyediaan air bersih untuk mandi dan cuci.

Adaptasi masyarakat terhadap lingkungan sungai hanya sebatas pada proteksi terhadap diri sendiri, tetapi tidak memperhitungkan akibat yang diterima oleh lingkungan akibat dari adaptasi yang dilakukan. Orientasi rumah membelakangi sungai Kali Kaca menciptakan limbah MCK dan sampah yang langsung dibuang ke sungai Kali Kaca.
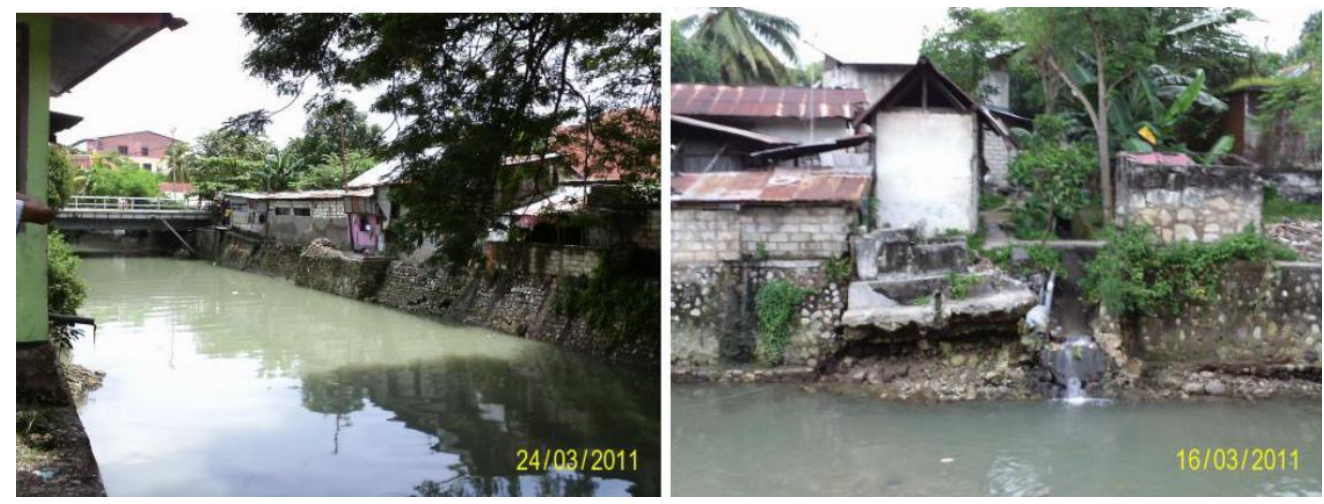

Gambar 6. Orientasi rumah membelakangi sungai Kali Kaca dimanfaatkan untuk limbah MCK Sumber: dokumentasi pribadi 


\subsection{Faktor Non Fisik}
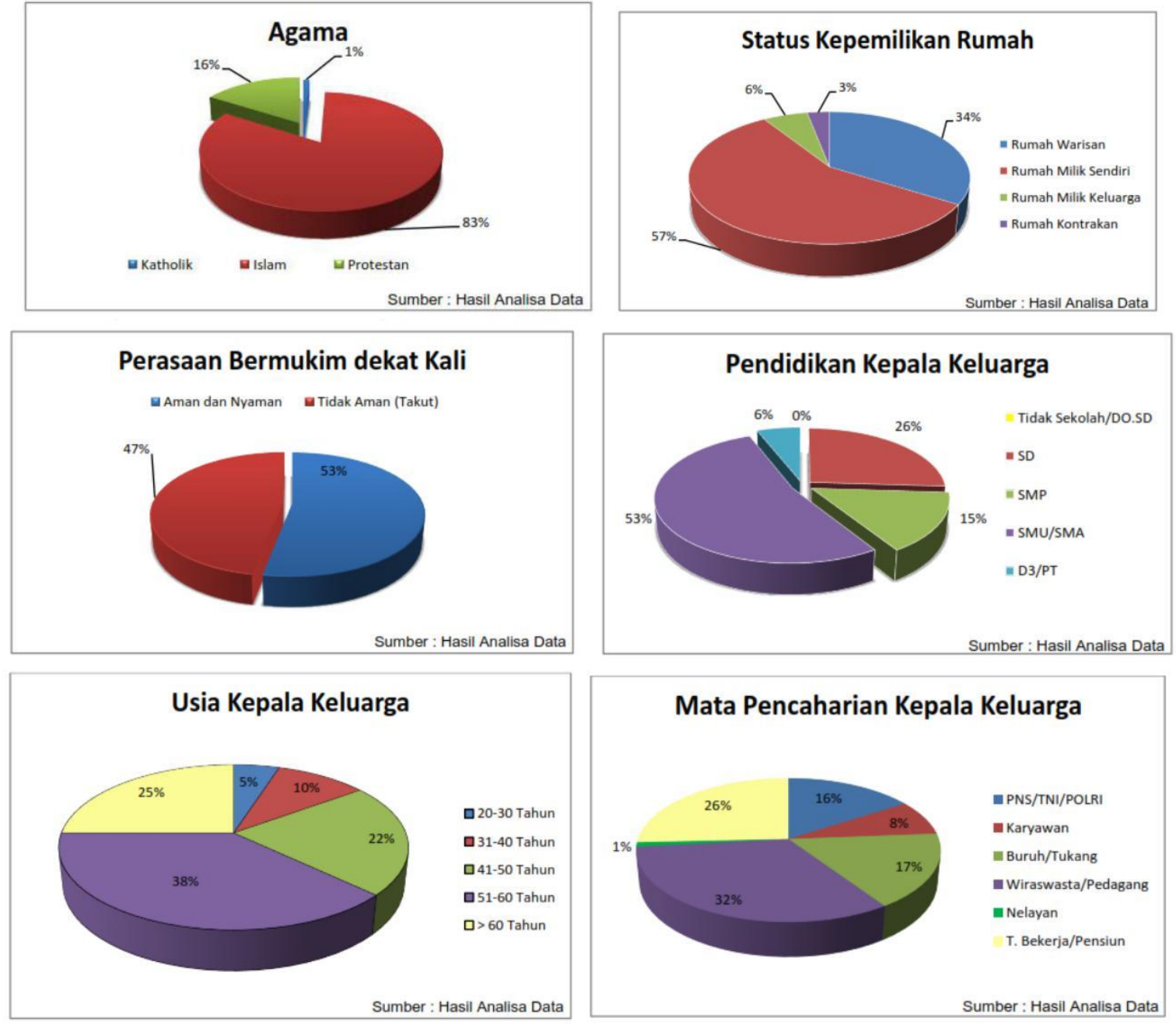

Gambar 7. Diagram faktor non fisik

\subsection{Faktor Fisik Bangunan}

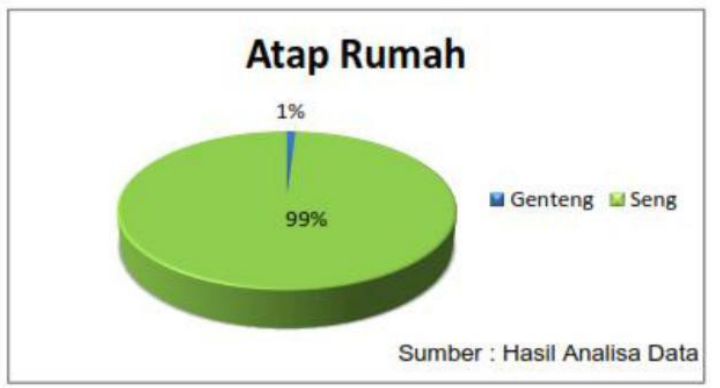

Pemanfaatan Material Bangunan dari Kali

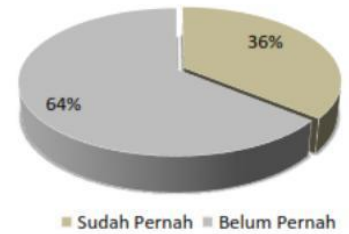

Sumber : Hasil Analisa Data

Gambar 8. Diagram faktor fisik bangunan: atap dan material bangunan 


\subsection{Faktor Fisik Lingkungan}

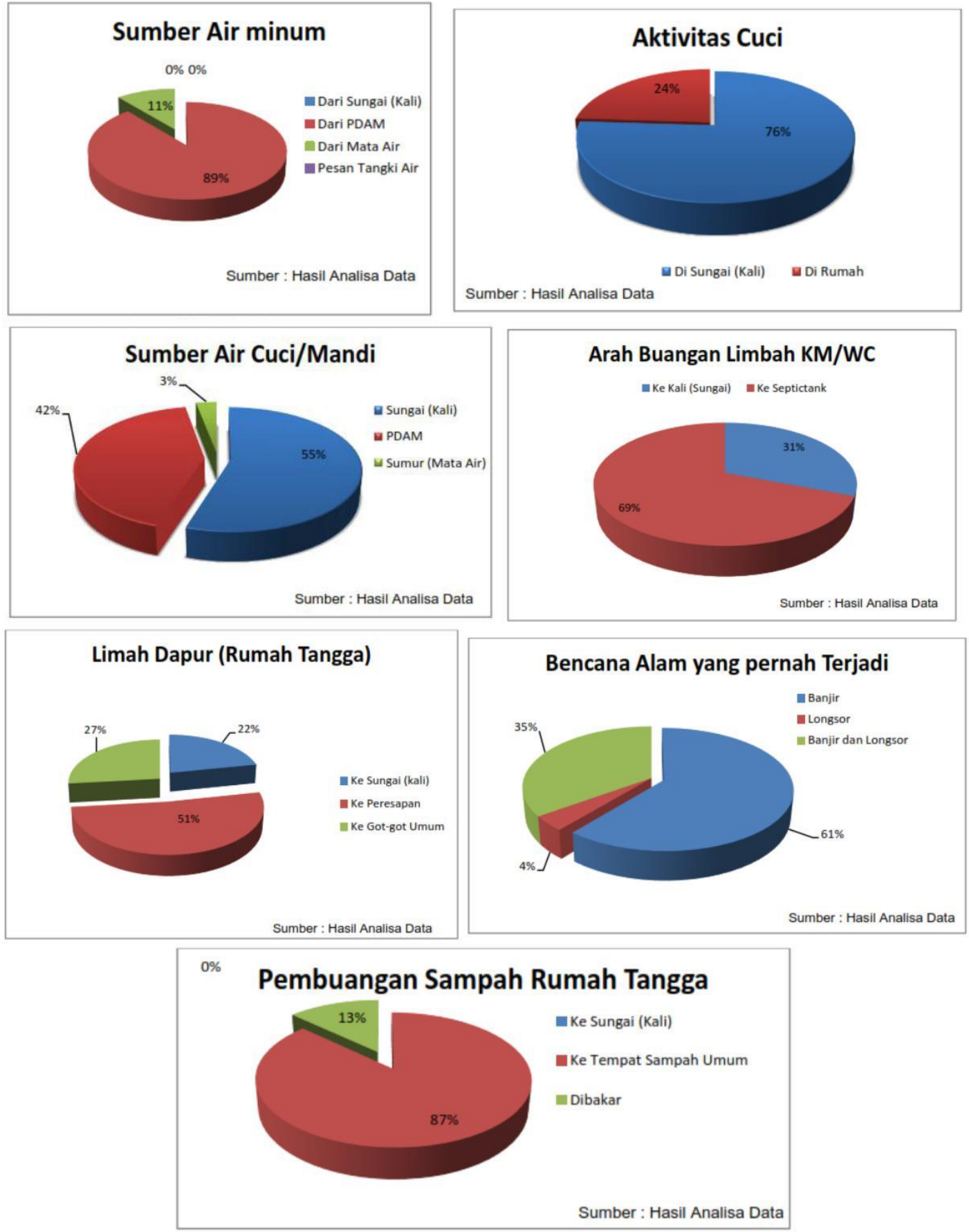

Gambar 9. Diagram faktor fisik lingkungan

Selain analisis faktor dominan yang mempengaruhi kondisi permukiman Airmata (keterkaitan penghuni permukiman bantaran sungai dengan sungai), juga dianalisis perubahan bentuk bangunan dan perubahan kegiatan sosial budaya pada masyarakat yang menghasilkan faktor penyebab perubahan, yaitu:

a. Bertambahnya jumlah rumah akibat dari pertambahan penduduk dan urbanisasi;

b. Bertambahnya jalur sirkulasi darat;

c. Keinginan memperoleh rumah yang layak dan kemudahan mendapatkan keperluan kehidupan sehari-hari tanpa meneluarkan biaya karena keterbatasan finansial penghuni

d. Berkurangnya minat untuk mempergunakan sarana transportasi sungai karena adanya sarana transportasi lain dan kurangnya campur tangan Pemerintah untuk membenahi transportasi sungai. 
Untuk menata keberlanjutan suatu permukiman maka harus diperhatikan unsur-unsur di dalam permukiman tersebut, karena menurut (Doxiadis, 1968) unsur-unsur pembentuk permukiman saling terkait dan saling mempengaruhi satu sama lain. Unsur-unsur permukiman itu adalah alam, manusa, kehidupan bermasyarakat, tempat berlindung dan sarana prasarana permukiman (networking).

Berikut kriteria penataan keberlanjutan permukiman di bantaran sungai berdasakan analisis sesuai pendekatan (Doxiadis, 1968) yaitu:

a. Menghidupkan kegiatan ekonomi di sungai dengan cara meletakkan simpul-simpul pasar di antara beberapa permukiman pinggir sungai

b. Menata permukiman dengan mempertimbangkan orientasi kawasan tertuju ke sungai; fasade bangunan ke arah sungai; aksesibilitas dua arah, dari sungai ke darat dan dari darat ke sungai; adanya hubungan antara jalan darat beserta fasilitas publiknya dengan sungai; dan tampilan sungai terlihat dari daratan;

c. Memperbaiki sanitasi lingkungan menggunakan teknik baru dengan masih mempertimbangkan kebiasaan masyarakat dalam berinteraksi dengan sungai;

d. Menghentikan pertumbuhan permukiman baru di tepi sungai;

e. Membongkar bangunan ilegal dan berumur kurang dari 50 tahun untuk dipindahkan ke tempat lain;

f. Menjaga ekosistem sungai dengan cara mengendalikan sedimenentasi sungai dan kebersihan sungai.

\section{KESIMPULAN}

Dari seluruh uraian di atas disimpulkan terdapat perubahan pola permukiman Airmata yakni pola orientasi bangunan dari sungai ke darat akibat faktor munculnya sirkulasi-sirkulasi jalan baru yang ada di darat. Permukiman bantaran sungai Kali Kaca patur untuk ditata agar terjaga kelestariannya karena mempunyai kehidupan bermukim yang khas menyangkut interaksi dan ketergantungannya kepada sungai. Konsep keberlanjutan yang diperoleh dari analisis terhadap permukiman bantaran sungai Kali Kaca meliputi penataan kegiatan ekonomi di sungai, penataan permukiman bantaran sungai, penataan serta pengendalian lingkungan sungai. Ketiga konsep harus dilaksanakan bersamaan karena ketiganya saling berkaitan satu sama lain.

\section{PUSTAKA}

Airmata, P. D. (2017). Laporan Bulanan Januari 2017 Kecamatan Kota Lama Kelurahan Airmata. Kupang: Kecamatan Kota Lama Kelurahan Airmata.

Chair, M. (2002). Banjarmasin, Karakteristik dan Faktor Yang Mempengaruhi Kondisi Permukiman di Kawasan Sekitar Aliran Sungai Martapura. Semarang: Pasca Sarjana Universitas Diponegoro.

Doxiadis, C. A. (1968). Existic an Introduction to The Sciende of Human Settlement.

Goenmiandari, B. (2010). Konsep Penataan Permukiman Bantaran Sungai di Kota Banjarmasin berdasarkan Budaya Setempat. Surabaya: Pasca Sarjana ITS.

https://id.wikipedia.org/wiki/Masjid_Agung_Al-Baitul_Qadim.

Indonesia, P. R. (1992). Undang-undang Republik Indonesia nomor 5 tahun 1992 tentang Benda Cagar Budaya. Jakarta: Undang-undang RI.

Lake, R. C. (2011). Karakteristik dan Faktor Keterkaitan Kondisi Permukiman Airmata sekitar Aliran Kali Kaca. Kupang: Tidak dipublikasikan.

Purbadi, Y. D. (2017). Continuity and Change Dalam Arsitektur Vernakular Kajian Fenomena Lopo Di Desa Kaenbaun. Seminar Nasional Riset dan Teknologi Terapan (hal. 70). Kupang: Program Studi Teknik Arsitektur Fakultas Teknik Universitas Katolik Widya Mandira.

Spradley, J. P. (1997). Metode Etnografi, Terjemahan Misbah Yulfa Elisabeth. Yogya: PT. Tiara Wacana.

Surtiani, E. E. (2006). Faktor-faktor yang Mempengaruhi Terciptanya Kawasan Permukiman Kumuh di Kawasan Pusat Kota. Semarang: Pasca Sarjana Universitas Diponegoro. 